University for Business and Technology in Kosovo

UBT Knowledge Center

Oct 28th, 9:00 AM - Oct 30th, 5:00 PM

\title{
Prediction of Punching Shear Capacity of Two-Ways FRP Reinforced Concrete Slabs
}

\author{
Ilker Fatih Kara \\ Bursa Technical University, ilker.kara@btu.edu.tr \\ Besian Sinani \\ University for Business and Technology, besian.sinani@ubt-uni.net
}

Follow this and additional works at: https://knowledgecenter.ubt-uni.net/conference

Part of the Engineering Commons

\section{Recommended Citation}

Kara, Ilker Fatih and Sinani, Besian, "Prediction of Punching Shear Capacity of Two-Ways FRP Reinforced Concrete Slabs" (2016). UBT International Conference. 15.

https://knowledgecenter.ubt-uni.net/conference/2016/all-events/15

This Event is brought to you for free and open access by the Publication and Journals at UBT Knowledge Center. It has been accepted for inclusion in UBT International Conference by an authorized administrator of UBT Knowledge Center. For more information, please contact knowledge.center@ubt-uni.net. 
Book of Proceedings

International Conference on Civil Engineering, Infrastructure and Environment

\title{
Prediction of Punching Shear Capacity of Two-Ways FRP Reinforced Concrete Slabs
}

\author{
Ilker Fatih Kara ${ }^{1}$, Besian Sinani² \\ Faculty of Natural Science, Architecture and Engineering, Department of Civil \\ Engineering, Bursa Technical University, 16330, Bursa, Turkey, \\ Department of Civil Engineering, Engineering Faculty, Niğde University, 51245 Niğde, \\ Institution /affiliation: UBT College,Faculty of Civil Engineering-Construction and \\ Infrastructure, 10000, Prishtina, Kosovo \\ ilker.kara@btu.edu.tr ${ }^{1}$, besian.sinani@ubt-uni.net ${ }^{2}$
}

\begin{abstract}
An innovative solution to the corrosion problem is the use of fiber-reinforced polymer (FRP) as an alternative reinforcing material in concrete structures. In addition to the non corrodible nature of FRP materials, they also have a high strength-to-weight ratio that makes them attractive as reinforcement for concrete structures. Extensive research programs have been carried out to investigate the flexural behavior of concrete members reinforced with FRP reinforcement. On the other hand, the shear behavior of concrete members, especially punching shear of two-way slabs, reinforced with FRP bars has not yet been fully explored. The existing provisions for punching of slabs in most international design standards for reinforced concrete are based on tests of steel reinforced slabs. The elastic stiffness and bonding characteristics of FRP reinforcement are sufficiently different from those of steel to affect punching strength. In the present study, the equations of existing design standards for shear capacity of FRP reinforced concrete beams have been evaluated using the large database collected. The experimental punching shear strengths were compared with the available theoretical predictions, including the CSA S806 (CSA 2012), ACI-440.1R-15 (ACI 2015), BS 8110 (BSI 1997), JSCE (1997) a number of models proposed by some researchers in the literature. The existing design methods for FRP reinforced concrete slabs give conservative predictions for the specimens in the database. This paper also presents a simple yet improved model to calculate the punching shear capacity of FRPreinforced concrete slabs. The proposed model provides the accurate results in calculating the punching shear strengths of FRP-reinforced concrete slender slabs.
\end{abstract}

Keywords: Punching shear, Fiber-reinforced polymer, Two-way slab, Concrete

\section{Introduction}

The use of fiber reinforced polymer (FRP) as an alternative reinforcement in concrete structures has emerged as an innovative solution owing to their non-corrosive and non-magnetic properties, making them ideal for severe environments and situations where magnetic transparency is required. Furthermore, FRP bars have a high strength-to-weight ratio, making them attractive as reinforcement for concrete structures. However, due to the relatively low modulus of elasticity of FRP bars compared 
Prediction of Punching Shear Capacity of Two-Ways FRP Reinforced Concrete Slabs

with steel bars, concrete members reinforced with FRP develop wider and deeper cracks than members reinforced with steel. The overall shear capacity of concrete members reinforced with FRP bars as flexural reinforcement is lower than that of concrete members reinforced with steel bars. Extensive research programs have been conducted to investigate the flexural behavior of concrete members reinforced with FRP reinforcement. The shear behavior of FRP reinforced concrete (RC) beams has also been studied, however, punching shear of two-way slabs, reinforced with FRP bars has not been sufficiently explored. Limited studies, have been conducted on the punching-shear behavior of slabs reinforced with the FRP bars/grids [1-5]. The FRP-reinforced slabs in these research studies exhibited lower punching-shear capacities, lower postcracking stiffness, and greater crack widths than those of their counterparts reinforced with steel bars when the same reinforcement amount was used. This was caused from smaller dowel action and smaller uncracked compression zone as a result of a lower modulus of elasticity of FRP bars in comparison with that of steel bars [6].

Ospina et al. (2003) [3] reported that the behavior of an FRP-RC slab-column connection is affected by the elastic stiffness of the reinforcing material as well as the quality of its bond characteristics with the concrete. However, the FRP grids may not provide the same punching-shear capacity as the FRP bars owing to the difference in bond behaviour and concentration of stresses in the grids. NguyenMinh and Rovnak [5] concluded that both the size factor and the effect of the span-to-effective-depth ratio $(\mathrm{L}=\mathrm{d})$ should be taken into account in computing the punching-shear resistance of the FRP-RC slab-column connections. Zhang et al. [7] reported that the reinforcement type significantly influenced the punching strength of slabs and the concrete strength significantly affeced the load carrying capacity and the post-punching capacity of slabs. However, it was found to be a little influence on the stiffness of the cracked slabs.

There is a few design and prediction models related to the punching shear strength of concrete slabs reinforced with FRP composite bars. This paper evaluates the accuracy of the available punching shear equations for FRP-RC slabs in the models of CSA S806 (CSA 2012) [8], ACI-440.1R-15 (ACI 2015) [9], BS 8110 (BSI 1997) [10], JSCE (1997) [11], El-Ghandour et al. [12], Matthys and Taerwe [2], Ospina et al. [3] and El-Gamal et al. [12] . The accuracy of the design equations and different models was assessed by comparing their predictions against the experimental results. This paper also presents a simple yet improved model to calculate the punching shear capacity of FRP-reinforced concrete slabs. The performance of the proposed model is also compared to that of punching shear design provisions and a number of models propsed by some researches.

\section{Experimental Database and Test Technique}

The punching shear strength results of 57 FRP reinforced concrete slabs were collected from published literature $[1-5,7,12-17]$ to evaluate the current shear design guidelines, predicted models and calibrate the proposed equation in this study. All specimens were FRP-reinforced concrete slab-column connections without column capitals and drop panels. All the slabs were tested under concentric punching load and failed in punching shear before reaching the design flexural capacity. Table 1 gives the distribution of the main shear design parameters in the database. They cover a relatively wide range of the material and geometric properties of FRP-reinforced concrete slabs. (The concrete cylinder compressive strength (fc), for the analyzed database ranges from 26 to $118 \mathrm{MPa}$, the young's modulus of FRP bars $\left(\mathrm{E}_{\mathrm{fl}}\right)$ ranges from 28 to $148 \mathrm{GPa}$, the ratio of flexure reinforcement $\left(\rho_{\mathrm{fl}}\right)$, ranges from $0.15 \%$ to $3.8 \%$ while the slab's effective depth (d) for the analyzed database ranges from 55 to $284 \mathrm{~mm}$.)

Table 1 Distribution of punching shear design parameters included in the database. 
Book of Proceedings

International Conference on Civil Engineering, Infrastructure and Environment

\begin{tabular}{llllllll}
\hline \multicolumn{1}{c}{$\begin{array}{c}\text { Effective depth } \\
\mathrm{d}\end{array}$} & \multicolumn{2}{c}{$\begin{array}{c}\text { Concrete } \\
\text { compressive } \\
\text { strength } \\
\text { f'c }\end{array}$} & \multicolumn{2}{c}{$\begin{array}{c}\text { Modulus of } \\
\text { elasticity } \\
\text { Efl }\end{array}$} & \multicolumn{2}{c}{$\begin{array}{c}\text { Reinforcement ratio } \\
\rho_{\mathrm{fl}}(\%)\end{array}$} \\
\hline $\begin{array}{l}\text { Range } \\
(\mathrm{mm})\end{array}$ & Frq. & $\begin{array}{l}\text { Range } \\
(\mathrm{MPa})\end{array}$ & Frq. & $\begin{array}{c}\text { Range } \\
(\mathrm{GPa})\end{array}$ & Frq. & Range & Frq. \\
\hline $50-80$ & 7 & $20-30$ & 7 & $20-40$ & 4 & $0.1-0.25$ & 4 \\
\hline $80-110$ & 16 & $30-40$ & 37 & $40-60$ & 35 & $0.25-0.45$ & 7 \\
\hline $110-140$ & 19 & $40-50$ & 8 & $60-80$ & 1 & $0.45-0.65$ & 4 \\
\hline $140-170$ & 5 & $50-60$ & 1 & $80-100$ & 9 & $0.65-0.85$ & 9 \\
\hline $170-200$ & 0 & $60-70$ & 0 & $100-120$ & 6 & $0.85-1.25$ & 16 \\
\hline $200-300$ & 10 & $70-120$ & 4 & $120-150$ & 2 & $1.25-3.75$ & 17 \\
\hline
\end{tabular}

\section{Punching Shear Design Provision}

Most of the current punching-shear strength equations for FRPRC slabs are mainly based on the design formulas for concrete members reinforced with steel and modified to account for the difference between FRP and steel reinforcements. This section evaluates the accuracy of the available punching shear equations for FRP-RC slabs in codes and design guidelines in CSA S806-12 [8], ACI-440.1R-15 [9], BS 8110 [10], and JSCE (1997), and a number of models proposed by El-Ghandour et al. [1], Matthys and Taerwe [2], Ospina et al. [3] and El-Gamal et al. [12]. The accuracy of the design equations was assessed by comparing their predictions against the experimental results (The applicability of the the design equations and different models has been tested by a comparison of the predicted and experimental results). The available punching-shear equations provided by FRP design codes, and proposed by different researchers are summarized below.

\subsection{ACI-440.1R-15 (ACI 2015)}

The ultimate punching-shear strength for the two-way concrete slabs reinforced with FRP bars according to the ACI-440.1R-15 is calculated as given in Eq. 1.

$\mathrm{V}_{\mathrm{c}}=\frac{4}{5} \sqrt{\mathrm{f}_{\mathrm{c}}} \mathrm{b}_{0 ; 0.5 \mathrm{~d}} \mathrm{kd}$

where $b_{o}$ is the critical perimeter at a distance of $d / 2$ away from the loaded area, and $d$ is the average flexural depth of the slab, $f_{c}$ is the concrete compressive strength.

\subsection{CSA S806-12 (CSA 2012)}

The punching-shear strength provided by CSA S806-12 is the smallest of Eqs. (2) to (4).

$\mathrm{V}_{\mathrm{c}}=0.056 \lambda \Phi_{\mathrm{c}}\left(\mathrm{E}_{\mathrm{fl}} \rho_{\mathrm{fl}} \mathrm{f}_{\mathrm{c}}\right)^{1 / 3} \mathrm{~b}_{0 ; 0.5 \mathrm{~d}} \mathrm{~d}$
$\mathrm{~V}_{\mathrm{c}}=0.028 \lambda \Phi_{\mathrm{c}}\left(1+\frac{2}{\beta_{\mathrm{c}}}\right)\left(\mathrm{E}_{\mathrm{fl}} \rho_{\mathrm{fl}} \mathrm{f}_{\mathrm{c}}\right)^{1 / 3} \mathrm{~b}_{0 ; 0.5 \mathrm{~d}} \mathrm{~d}$ 
$V_{c}=0.147 \lambda \Phi_{c}\left(0.19+\frac{\alpha_{s} d}{b_{0 ; 0.5 d}}\right)\left(E_{f l} \rho_{f l} f_{c}\right)^{1 / 3} b_{0 ; 0.5 d} d$

where $\rho_{f l}$ and $E_{f l}$ are the reinforcement ratio and modulus of elasticity (in GPa) of the main bottom reinforcement, respectively; $\lambda=$ concrete density factor ( 1 for normal weight and 0.85 for semilightweight); $\Phi$ c concrete resistance factor.

\subsection{British Standard BS 8110 (BSI 1997)}

The BSI 8110 provides the following equation for calculating the punching shear strength of FRP reinforced concrete slab,

$V_{c}=0.79\left[\left(100 \rho_{f}\left(E_{f l} / E_{s}\right)\right]^{1 / 3}\left(\frac{f_{c u}}{25}\right)^{\frac{1}{3}}\left(\frac{400}{d}\right)^{1 / 4} b_{0 ; 1.5 d} d\right.$

\subsection{Japanese Design Recommendations (JSCE 1997)}

The punching-shear strength according to JSCE (1997) is determined as given in Eq. (6):

$\mathrm{V}_{\mathrm{c}}=\beta_{\mathrm{d}} \beta_{\mathrm{p}} \beta_{\mathrm{r}} \mathrm{f}_{\mathrm{pcd}} \mathrm{b}_{0 ; 0.5 \mathrm{~d}} \mathrm{~d} / \gamma$

$\beta_{\mathrm{d}}=\left(\frac{1000}{\mathrm{~d}}\right)^{1 / 4} \leq 1.5$

$\beta_{\mathrm{p}}=\left(\frac{100 \rho_{\mathrm{f}} \mathrm{E}_{\mathrm{fl}}}{\mathrm{E}_{\mathrm{s}}}\right)^{1 / 3} \leq 1.5$

$\beta_{\mathrm{r}}=1+1 /\left(1+\frac{0.25 \mathrm{u}}{\mathrm{d}}\right)$

$\mathrm{f}_{\mathrm{pcd}}=0.2 \sqrt{\mathrm{f}}_{\mathrm{c}} \leq 1.2 \mathrm{MPa}$

where $\mathrm{u}$ is the perimeter of the loaded area.

\subsection{Other Punching-Shear Equations}

El-Ghandour et al. [12] suggested a modified form of the ACI 318-95 [18] equation by multiplying it by $(\mathrm{Efl} / \mathrm{Es}) 1 / 3$, as shown in Eq. 7.

$\mathrm{V}_{\mathrm{c}}=0.33 \sqrt{\mathrm{f}_{\mathrm{c}}}\left(\mathrm{E}_{\mathrm{f}} \mathrm{l} / \mathrm{E}_{\mathrm{s}}\right)^{1 / 3} \mathrm{~b}_{0 ; 0.5 \mathrm{~d}} \mathrm{~d}$

Mattys and Taerwe [2] recommended the following equation for the punching-shear strength of slabs reinforced with FRP bars, as a modification of the BS 8110 (1997) equation,

$V_{c}=1.36\left[\left(100 \rho_{f} f_{c}\left(E_{f l} / E_{s}\right)\right]^{1 / 3}\left(\frac{1}{d}\right)^{1 / 4} b_{0 ; 1.5 d} d\right.$

El-Gamal et al. [1] suggested a new parameter ( $\alpha$ ), including the axial stiffness of the tensile reinforcement ( $\rho \mathrm{fEf}$ ), the perimeter of the applied load, and the effective depth of the slab for the ACI 318-05 design code equation, as follows: 
Book of Proceedings

International Conference on Civil Engineering, Infrastructure and Environment

$\mathrm{V}_{\mathrm{c}}=0.33 \sqrt{\mathrm{f}_{\mathrm{c}}} \mathrm{b}_{0 ; 0.5 \mathrm{~d}} \mathrm{~d} \alpha$

$\alpha=0.5\left(\rho_{\mathrm{f}} \mathrm{E}_{\mathrm{fl}}\right)^{\frac{1}{3}}\left(1+\frac{8 \mathrm{~d}}{\mathrm{~b}_{0 ; 0.5 \mathrm{~d}}}\right)$

\subsection{Proposed Design Equation}

The present proposed new equation is considered as a modification of Eq. (8), by replacing the coefficient 0.46 instead of 1.36 and removed the $d$ parameter from that of equation. Consequently, the new proposed model will be in this form:

$\mathrm{V}_{\mathrm{c}}=0.46\left[\left(100 \rho_{\mathrm{f}} \mathrm{f}_{\mathrm{c}}\left(\mathrm{E}_{\mathrm{fl}} / \mathrm{E}_{\mathrm{s}}\right)\right]^{1 / 3} \mathrm{~b}_{0 ; 1.5 \mathrm{~d}} \mathrm{~d}\right.$

\section{Comparison between experimental and predicted results}

The accuracy of the punching-shear equations were assessed herein by comparing their predictions with the 57 experimentally tested by the authors from the literature [1-5, 7, 12-17]. The safety factors included in all the punching-shear equations were set to 1.0 for comparison purposes. Each design method was evaluated based on mean, standard deviation (STD), coefficient of variation (COV) of experimental to predicted punching shear capacity ratio $\left(\mathrm{V}_{\text {exp }} / \mathrm{V}_{\text {pred }}\right)$ of individual formulas and the average absolute error (AAE) calculated as following equation and listed in Table 2.

$\mathrm{AAE}=\frac{1}{n} \sum \frac{\left|V_{\text {exp }}-V_{\text {pred }}\right|}{V_{\text {exp }}} \times 100$

Table 2 Statistical coefficients of the proposed and shear design equations.

\begin{tabular}{lcccc}
\hline \multirow{2}{*}{ Method } & \multicolumn{3}{c}{ Vexp/Vpred } & \multirow{2}{*}{ AAE $(\%)$} \\
\cline { 2 - 4 } & Mean & SD & COV $(\%)$ & \\
\hline ACI 440.1R-15 & 2.52 & 0.75 & 30.0 & 35.7 \\
\hline CAN/CSA-S806-12 & 1.39 & 0.45 & 32.5 & 23.2 \\
\hline BS 8110 & 1.25 & 0.16 & 12.6 & 19.2 \\
\hline JSCE-97 & 1.46 & 0.39 & 26.5 & 27.8 \\
\hline El-Ghandour et al. [1] & 1.49 & 0.61 & 41.0 & 16.1 \\
\hline Mattys and Taerwe [2] & 1.19 & 0.15 & 12.6 & 14.5 \\
\hline El-Gamal et al. [12]. & 1.1 & 0.21 & 19.2 & 10.0 \\
\hline Proposed Eq. & 1.05 & 0.13 & 12.5 & .
\end{tabular}

Table 2 shows that the ACI 440.1R-15 design method provides the most conservative predictions and scatter with all predictions in the conservative side and mean ratio of Vexp/Vpred of 2.52. Shear design equations of BS 8110, CSA S806-12 and JSCE-97 provide better results than that of ACI-440.1R-15. The direct implementation of the FRP axial stiffness into the punching-shear equations of CSA S80612, JSCE-97 and BS 8110 in the punching-shear equations provided good predictions. The high 
Prediction of Punching Shear Capacity of Two-Ways FRP Reinforced Concrete Slabs

conservativeness level of this equation may be caused from the absence of the axial stiffness of the reinforcement in the punching-shear equation. The model proposed by El-Gamal et al. [12] gives better results than all design equations and other models with mean ratio of $\mathrm{V}_{\text {exp }} / \mathrm{V}_{\text {pred }}$ of 1.1 . On the other hand, the proposed equation provides the most reasonable prediction and least scatter for punching shear strength of FRP reinforced concrete beams with an average ratio of Vexp/Vpred equal to 1.00. The proposed equation also provided the lowest AAE of $16.6 \%$ compared with $35.7 \%$ for ACI 440.1R$15,23.2 \%$ for CSA S $806-12,27.8 \%$ for JSCE $97,19.2 \%$ for BIS $8110,29.2 \%$ for El-Ghandour et al. [1], $16.1 \%$ for Mattys and Taerwe [2] and 14.5\% El-Gamal et al. [1].

\section{Conclusions}

This paper assessed the accuracy of the available punching shear design equations for FRP-RC slabs. The BISE 8110 provided the most reasonable prediction among existing punching shear design standart or guidlines. However, the model of El-Gamal et al. gave better results than BISE 8110. On the other hand, the proposed model provived the most accurate results results in calculating the punching shear strength FRP-RC slabs among existing shear equations considered. The theoretical results indicated that the direct implementation of the FRP axial stiffness into the punching-shear equations provided good predictions.

\section{References}

1. El-Ghandour, A. W., Pilakoutas, K., and Waldron, P. Punching shear behavior of fiber reinforced polymers reinforced concrete flat slabs: Experimental study. J. Compos. Constr., 7(3) (2003) 258265.

2. Matthys, S., and Taerwe, L.. Concrete slabs reinforced with FRP grids. II: Punching resistance. J. Compos. Constr. 4(3) (2000) 154-161.

3. Ospina, C. E., Alexander, S. D. B., and Roger Cheng, J. J. Punching of two-way concrete slabs with fiber-reinforced polymer reinforcing bars or grids. ACI Struct. J. 100(5) (2003) 589-598.

4. Lee, J. H., Yoon, Y. S., and Mitchell, D. Improving punching shear behavior of glass fiberreinforced polymer reinforced slabs. ACI Struct. J., 106(4) (2009) 427-434.

5. Nguyen-Minh, L., and Rovnak, M. Punching-shear resistance of interior GFRP reinforced slabcolumn connection. J. Compos. Constr. (2013) 2-13.

6. Hassan M, Ahmed EA, Benmokrane B. Punching-shear strength of GFRPreinforced concrete flat slabs. Can J Civil Eng 40(10) 2013951-60.

7. Zhang, Q., Marzouk, H., and Hussein, A. A preliminary study of high-strength concrete two-way slabs reinforced with GFRP bars. Proc., 33rd CSCE Annual Conf.: General Conference and International History Symposium, Canadian Society of Civil Engineers, Toronto ON (2005) Canada.

8. Canadian Standards Association (CSA). Design and construction of building structures with fibre reinforced polymers. CAN/CSA S806- 12. Rexdale, ON (2012). Canada.

9. American Concrete Institute (ACI). "Guide for the design and construction of concrete reinforced with FRP bars.” ACI 440.1R-15 (2006). Farmington Hills, MI.

10. British Standards Institution (BSI). Structural use of concrete: Part 1 -Code of practice for design and construction. BS8110 (1997) London. 
Book of Proceedings

International Conference on Civil Engineering, Infrastructure and Environment

11. Japan Society of Civil Engineers (JSCE). Recommendation for design and construction of concrete structures using continuous fibre reinforcing materials. Concrete Engineering, Series 23, A. Machida, ed. (1997). Tokyo, Japan.

12. El-Gamal, S., El-Salakawy, E., Benmokrane, B. Behavior of concrete bridge deck slabs reinforced with fiber-reinforced polymer bars under concentrated loads. ACI Struct. J. 102 (2005) 727-735.

13. Zaghloul, A.E., Razaquur A.G. Punching shear behavior of CFRP reinforced concrete flat plates, in: D. Bruno, G. Spadea, R.N. Swamy (Eds.), Proceedings of the international conference on composites in construction. 2003, pp.1-726.

14. Hassan M., Ahmed E.A., Benmokrane B. Punching-shear strength of normaland high-strength twoway concrete slabs reinforced with GFRP bars. ASCE. J.. Compos. Constr. 2013. http://dx.doi.org/10.1061/(ASCE) CC.1943-5614.0000424.

15. Hussein A, Rashid I, Benmokrane B. Two-way concrete slabs reinforced with GFRP bars. In: Proc., 4th Int. Conf. on Advanced Composite Materials in Bridges and Structures, Calgary, AB, Canada: CSCE; 2004. p. 8.

16. Ahmad S.H., Zia P., Yu T., Xie Y. Punching shear tests of slabs reinforced with 3-D carbon fiber fabric. ACI Concr Int (1993) 16(6) 36-41.

17. Banthia N., Al-Asaly M., Ma S. Behavior of concrete slabs reinforced with fiberreinforced plastic grid. J. Mater. Civil. Eng. 7(4) (1995) 252-7.

18. ACI Committee 318, Building Code Requirements for Structural Concrete and Commentary. ACI 318-11, American Concrete Institute, Farmington Hills, 2011. 